\title{
Empirically derived dietary patterns: interpretability and construct validity according to different factor rotation methods
}

\author{
Padrões alimentares empiricamente derivados: \\ interpretabilidade e validade de construto \\ segundo diferentes métodos de rotação fatorial
}

\author{
Patrones alimentarios empíricamente derivados: \\ interpretabilidad y validez de constructo, \\ según diferentes métodos de rotación \\ en un análisis factorial
}

\author{
1 Faculdade de Saúde \\ Pública, Universidade de São \\ Paulo, São Paulo, Brasil. \\ 2 Universidade Federal \\ Fluminense, Niterói, Brasil. \\ Correspondence \\ M. A. Castro \\ Faculdade de Saúde Pública, \\ Universidade de São Paulo. \\ Av. Dr. Arnaldo 715, São \\ Paulo, SP 01246-904, Brasil. \\ mi.ale.castro@gmail.com
}

\begin{abstract}
This study aimed to investigate the effects of factor rotation methods on interpretability and construct validity of dietary patterns derived in a representative sample of 1,102 Brazilian adults. Dietary patterns were derived from exploratory factor analysis. Orthogonal (varimax) and oblique rotations (promax, direct oblimin) were applied. Confirmatory factor analysis assessed construct validity of the dietary patterns derived according to two factor loading cut-offs $(\geq|0.20|$ and $\geq|0.25|)$. Goodness-of-fit indexes assessed the model fit. Differences in composition and in interpretability of the first pattern were observed between varimax and promax/oblimin at cutoff $\geq|0.20|$. At cut-off $\geq|0.25|$, these differences were no longer observed. None of the patterns derived at cut-off $\geq|0.20|$ showed acceptable model fit. At cut-off $\geq|0.25|$, the promax rotation produced the best model fit. The effects of factor rotation on dietary patterns differed according to the factor loading cut-off used in exploratory factor analysis.
\end{abstract}

Food Consumption; Food Habits; Public Health Nutrition; Statistical Factor Analysis
Michelle Alessandra de Castro ${ }^{1}$

Valéria Troncoso Baltar 2

Soraya Sant'Ana de Castro Selem 1

Dirce Maria Lobo Marchioni 1

Regina Mara Fisberg 1

\section{Resumo}

Objetivou-se investigar os efeitos dos métodos de rotação fatorial na interpretabilidade e validade de construto de padrões alimentares em uma amostra representativa de 1.102 adultos brasileiros. Os padrões foram derivados por análise fatorial exploratória. As rotações ortogonal (varimax) e oblíqua (promax $e$ oblimin direta) foram utilizadas. Avaliou-se a validade de construto dos padrões segundo os pontos de corte de cargas fatoriais: $(\geq|0,20| e \geq|0,25|)$ por meio de análise fatorial confirmatória. Índices de qualidade de ajuste do modelo foram analisados. Observaram-se diferenças na composição e interpretabilidade do primeiro padrão obtido pelas rotações varimax $e$ promax/oblimin no ponto de corte $\geq|0,20|$. No ponto de corte $\geq|0,25|$ não foram observadas diferenças. Nenhum dos padrões derivados no ponto de corte $\geq|0,20|$ apresentou qualidade de ajuste aceitável. No ponto de corte $\geq|0,25|$, a rotação promax obteve o melhor ajuste. Os efeitos das rotações nos padrões alimentares diferiram segundo o ponto de corte de carga fatorial utilizado na análise fatorial exploratória.

Consumo de Alimentos; Hábitos Alimentares; Nutrição em Saúde Pública; Análise Fatorial 


\section{Introduction}

Exploratory factor analysis (EFA) is a multivariate statistical method that has been used in nutritional epidemiology as a data-driven approach to derive dietary patterns. Dietary pattern analysis is of growing interest because it provides valuable and comprehensive information about the overall diet 1 , accounting for the synergistic relation between a myriad of foods and nutrients consumed 2,3 .

From a statistical perspective, EFA is concerned with modeling the covariance among observed variables in order to identify the latent constructs or factors underlying these variables 4 . In dietary pattern analysis, EFA combines, into a factor, food variables that are correlated to each other, but are independent of the other subset of variables 5 . The strength in which an observed variable correlates to a factor is measured by its factor loading 6 .

In order to simplify the factor structure (i.e. matrix of factor loadings) and improve the interpretability of the factor, a rotation method is usually applied after the extraction of a subset of factors ${ }^{5}$. A simple factor structure is achieved when the variable loads highly on as few factors as possible and the loadings of the variables across the factors (cross-loadings) are approximately zero 7,8 .

In dietary pattern analysis, the orthogonal varimax rotation has been the most commonly used rotation method 9,10. Orthogonal rotation leads to uncorrelated factors that are considered simpler and easier to interpret 8,10 , whereas nonorthogonal (oblique) rotation, such as promax and oblimin, allow producing correlated factors which are considered harder to interpret and, for this reason, have been used less in studies involving dietary pattern analysis 11,12,13,14,15,16,17.

Once estimated, the factor structure can be evaluated by confirmatory factor analysis (CFA). CFA is a powerful statistical method allowing for testing specific hypotheses about the factor structure by providing an indication of overall fit and precise criteria for assessing construct validity, i.e., the degree of correspondence between constructs and their measures 18,19,20. This method evaluates whether a pre-specified factor structure provides a good fit to the data 7 .

Considering that the effects of rotation methods on the factor structure, its interpretability and construct validity remain unclear in the field of nutritional epidemiology, the present study aimed to investigate the effects of both orthogonal and oblique rotation methods on composition, interpretability and construct validity of empirically derived dietary patterns. With this study it is expected to advance the current knowledge on procedures of factor analysis and to improve guidance for researchers interested in dietary pattern investigation.

\section{Materials and methods}

\section{Study population}

Data came from the Health Survey of the City of São Paulo, a cross-sectional population-based survey using a complex multistage sampling design to collect health and nutrition information as well as life conditions on a representative sample of residents of the city of São Paulo, Southeastern Brazil, between March 2008 and August 2011.

A two-stage cluster sampling of census tracts and households was performed. In the first stage, a total of 70 census tracts were randomly selected from the 267 urban census tracts in the city of São Paulo as the primary sampling units (PSU). In the second stage, 16,607 households were randomly selected within census tracts.

This sampling was drawn in order to interview infants ( $<1$ year-old); children (1-11 years); male adolescents (12-19 years); female adolescents (12-19 years); male adults (20-59 years); female adults (20-59 years); male elderly (60 years and over) and female elderly (60 years and over). For the present analysis, only individuals aged 20 years or more of both genders with complete food consumption data were selected $(\mathrm{N}=1,102)$.

The main study was conducted according to the guidelines laid down in the Declaration of Helsinki and all procedures involving human subjects were approved by the Human Research Ethics Committee of the School of Public Health at the University of São Paulo. Written informed consent was obtained from all participants who agreed to participate.

Socioeconomic, anthropometric and lifestyle data collection

A structured questionnaire with information about socioeconomic (per capita family income; educational level), anthropometric (body weight and height), demographic (skin color, age) and lifestyle characteristics [smoking status; alcohol use; physical activity - International Physical Activity Questionnaire (IPAQ)] was applied at the individual's home by trained interviewers. 


\section{Dietary data collection}

Dietary data were collected by both face-toface and telephone interviews. In the face-toface interview, the first 24-hour dietary recall (24HR) was collected according to procedures described in the USDA Five-Step Multiple Pass Method 21. This method guides the individual through a 24 hour reference period of food intake (more commonly, the day before interview) and provides different opportunities for individuals to remember and describe all foods and beverages he or she has consumed 21. During the telephone interview, the second $24 \mathrm{HR}$ was collected according to the interviewing system incorporated into the University of Minnesota's Nutrition Data System for Research (NDS-R). This interviewing system enhances data quality since it standardizes the probes about foods and portions consumed 22. All individuals were advised to report food consumption in household measures as well as to mention the eating occasions, meal time, cooking methods, seasonings and brand names. Quality control of the 24HR was conducted during data collection in order to identify and correctly report on errors. Dietary data collection occurred in non-consecutive days throughout all seasons and days-ofthe-week.

After dietary data collection, all household measures reported in each $24 \mathrm{HR}$ were converted into grams and milliliters according to Brazilian publications, which were also used to provide standard recipes of regional food preparations 23,24 . The NDS-R, version 2007, was also used to determine the nutrient content of each food and beverage consumed. This program was developed by the Nutrition Coordinating Center at the University of Minnesota, Minneapolis, USA, and has the USDA Food Composition Table as the primary database source.

\section{Foods grouping}

A total of 1,169 different foods were reported in both $24 \mathrm{HR}$ and were collapsed into 38 food groups for factor analysis. Foods consumed by at least $5 \%$ of the sample evaluated (948 foods) were combined according to the previously used criteria: similarity of the nutrient profile 25,26,27 (e.g., all types of coffees were combined into the "Coffee" group) and the particular dietary habits and culinary usage of the Southeastern Brazilian population 28 (e.g., "Beans" group includes brown and black beans because they are cooked pulses that are usually eaten with rice, whereas the "Other pulses" group includes soybeans, lentils, chickpeas and snow peas because these are usually consumed in different preparations, such as soups, creams and salads).

The correlation matrix of food groups was analyzed to identify how the food groups were correlated to each other. The correlation matrix revealed that four food groups (Cereals, Flours, Roots and Tubers, and Seafood) did not show a significant correlation ( $p$-value $>0.05$ ) with any other food group, and then were excluded from further analysis. A detailed description about the 34 food groups and its composition is provided in Table 1.

The food group intakes, in grams, were adjusted for the within-person variation through the web-based statistical modeling technique Multiple Source Method (MSM) before factor analysis. This is a statistical method developed within the European Food Consumption and Validation Project (EFCOVAL) which is suitable for estimating the usual nutrient and food intakes (including those episodically consumed) based on two or more short-term dietary methods such as $24 \mathrm{HR} 29$.

\section{Statistical analysis}

Sociodemographic, anthropometric and lifestyle characteristics of participants were described by sex and compared through a Chi-squared test. All descriptive analyses were conducted using Stata version 12.0 (Stata Corp., College Station, USA), considering the sampling design effect (svy command for proportion analysis) and significance level of $5 \%$.

Dietary patterns were derived from EFA using the robust maximum likelihood parameter estimation (MLR) available in Mplus software (version 6.12; Muthén \& Muthén, Los Angeles, USA) MLR was chosen because it is an estimation procedure appropriate to non-normally distributed data allowing for complex sampling designs and is also available for use in CFA ${ }^{30}$. It leads to more appropriate estimates than the conventional maximum likelihood estimation when the assumption of multivariate normal distribution does not hold 31 .

The Kaiser-Meyer-Olklin (KMO) test and Bartlett's sphericity test were used to measure the sample adequacy before deriving dietary patterns. KMO values above 0.50 and $\mathrm{p}$-value < 0.05 for Bartlett's sphericity test were considered acceptable 32 . The communalities of the food groups were calculated, representing the variance of each observed variable explained by the factor solution. Also, the percentage of variance explained by the factors was estimated for each rotation method. 
Description of the food groups used in the dietary pattern analysis. Health Survey of the City of São Paulo, Brazil, 2008-2011.

\begin{tabular}{|c|c|}
\hline Food groups & Food items \\
\hline Rice & Cooked white rice \\
\hline Pasta & Cooked noodles, gnocchi, lasagna, cannelloni \\
\hline Breads/Toasts/Crackers & French bread, Italian bread, loaf bread, buns, French toast, cookies, crackers \\
\hline Whole breads & Whole wheat bread, Light whole bread \\
\hline Fruits & Fresh fruits \\
\hline Leafy vegetables & Lettuce, kale, escarole, spinach, cabbage, watercress, chard, arugula \\
\hline Canned vegetables & Corn, peas, olives, hearts of palm, mushrooms, pickles \\
\hline Non-leafy vegetables & Tomato, carrot, beet, chayote, cucumber, eggplant, okra, pumpkin, zucchini \\
\hline Beef & Steak beef, ground beef, beef ribs (all cooking methods) \\
\hline Pork & Pork chop, pork ribs, pork loin (all cooking methods) \\
\hline Processed meat & Hamburger, sausages, frankfurters, nuggets, bacon, canned sardines, canned tuna \\
\hline Poultry & Chicken, turkey (all cooking methods) \\
\hline Chocolate powder & Cocoa powder, chocolate powder \\
\hline Yellow cheese & Mozzarella cheese, parmesan cheese, cheddar cheese, provolone cheese \\
\hline White cheese & White cheese, cottage cheese, ricotta cheese, cream cheese \\
\hline Whole milk & Fluid whole milk (3\% fat), whole milk powder \\
\hline Low-fat and skim milk & Reduced fat milk (2\% fat), skim milk, skim milk powder \\
\hline Other dairy products & Yoghurt, fermented milk \\
\hline Eggs & Fried eggs, scrambled eggs, omelet, boiled eggs, egg white, egg yolk \\
\hline Other pulses & Cooked soybeans, lentils, chickpeas, white beans, Adzuki beans, snow peas \\
\hline Beans & Cooked brown beans, black beans \\
\hline Butter and margarine & Salted butter, unsalted butter, salted margarine, unsalted margarine, light margarine \\
\hline Cakes and pastries & White cake, sweet pies, milk candy, chocolate pudding, peanut brittle, ice cream \\
\hline Salty snacks & French fries \\
\hline Sandwiches & Hot dog, hamburger sandwich, pizza, kebab, croquette, croissant, Italian focaccia \\
\hline Coffee and tea & Coffee, instant coffee, herbal tea \\
\hline Soda pop & Coke, diet coke, orange soda, lemon soda, guaraná soda \\
\hline Fruit juices & Natural fruit juices, Industrialized fruit juices \\
\hline Alcoholic beverages & Beer, wine, spirits, cognac, champagne \\
\hline Cold cuts & Ham, mortadella, salami, roast beef \\
\hline Salad dressing & Soybean oil, sunflower oil, olive oil, salt, vinegar \\
\hline Sugar & White sugar \\
\hline Fatty sauces and mayonnaise & White sauce, soy sauce, Worcestershire sauce, mustard sauce, ketchup, mayonnaise \\
\hline Spices & Garlic, oregano, scallions, parsley, coriander, ground pepper \\
\hline
\end{tabular}

In order to identify the number of factors to retain, the Kaiser criterion (eigenvalue $>1.0$ ) was used in the first step. This criterion is one of the most widely used in EFA with the rationale that the minimum variance explained by the factor should be equal to or greater than the variance of one single observed variable ${ }^{33}$. In this study, the Kaiser criterion would lead to the retaining of 14 factors which is an excessive number of factors for further analysis. Hence, a plot of the eigenvalues (the Cattell's scree test) was investigated in the second step and suggested two break points in the data that afforded two and four factor solutions (Figure 1). In the third step, the interpretability of two and four factor solutions was investigated. The two factor solution was more interpretable than the four factor solution and then was retained to investigate the effects of the factor rotations on the composition, interpretability and construct validity of each factor. For interpretation of the factor solution, food groups with a positive factor loading were considered as contributing directly to the factor, while food groups with negative loadings were considered 


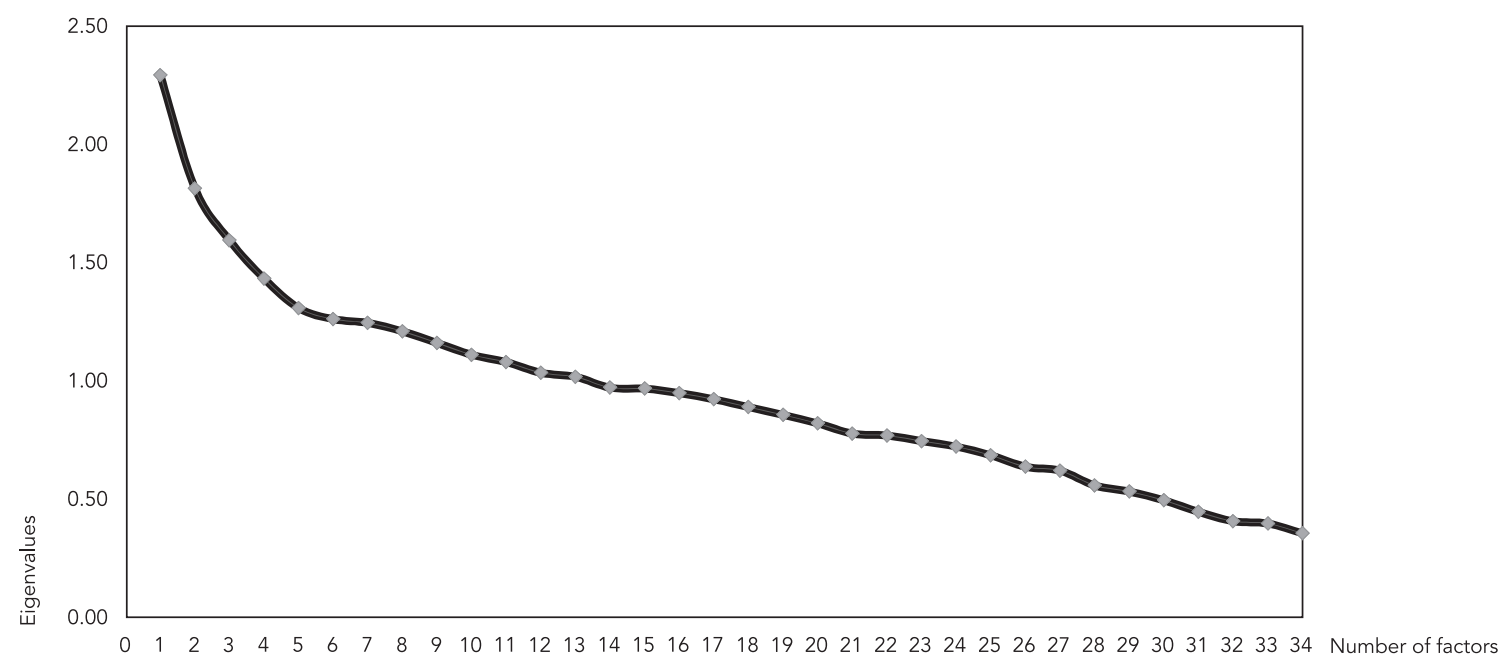

to be inversely correlated with the factor. Considering the methodological purposes of this study, the factors were presented in alphanumeric labels rather than descriptive names, in order to facilitate reporting of results.

The factor rotation selected for this research was the same as those reported in previous studies on dietary pattern analysis that used factor analysis or principal component analysis: the orthogonal varimax $34,5,6,37,38,39,40$, the oblique promax $11,12,13,14,15$ and direct oblimin 16,17 . In brief, the varimax is a type of orthogonal rotation that attempts to maximize the variance of squared loadings on a factor, i.e., to reduce the cross-loadings of the variables, leading to uncorrelated simple factor structures 41 . The promax is an oblique rotation that is performed in two stages. In the first one, the target matrix of loadings is first defined through a varimax rotation. This matrix of loadings is raised to some power (kappa) - usually ranging from 2 to 4 - aiming to produce a simple factor structure. The second stage is obtained by computing a least square fit from the target matrix 42 . In this study, the Mplus default promax rotation power (kappa $=4$ ) was used. Direct oblimin is another type of oblique rotation that aims to produce factors with perfect simple structure, i.e., factors with cross-loadings near zero or equal to zero. For this, a delta parameter ranging from 0 to 1 should be set. In this study, a delta equal to zero was chosen in an attempt to produce a simple factor structure 8,43 .

After rotation, two factor loading cut-offs were applied to select the food items to CFA: $\geq$ $|0.20|$ and $\geq|0.25|$. These cut-offs were chosen because they represent two factor loading cut-offs applied in dietary pattern studies $34,35,36,37,38,39,4$ $0,44,45,46,47,48,49$, that would lead, in this study, to a less restrictive number of food items than the most commonly applied cut-off (i.e., $\geq|0.30|$ ). The CFA was executed in Mplus software 6.12 to assess the construct validity of each dietary pattern derived using the MLR estimation method.

The goodness-of-fit of the model was assessed by different indexes namely the adjusted Chi-squared test ( $\chi^{2} /$ degrees of freedom) ${ }^{30}$, the comparative fit index (CFI) 50, the Tucker-Lewis index (TLI) 51, the residual mean square error of approximation (RMSEA) 52 and its $90 \%$ confidence interval $(90 \% \mathrm{CI})$, and the standardized root mean square residual (SRMR) 53,54. They provide different information about model fit, such as absolute fit, fit adjusting for model parsimony and fit relative to a null model, allowing for a more conservative and reliable evaluation of the model 53. Acceptable model fit was defined according to the following criteria: $\chi^{2 /}$ degrees of freedom $<3.030$, CFI $(>0.90) 50$, TLI $(>0.90){ }^{51}$, RMSEA $(\leq 0.06,90 \% \mathrm{CI}<0.08) 52$, and SRMR $(\leq 0.08) 53,54$. A p-value $<0.05$ was considered as significant in two-sided tests. Both EFA 
and CFA were performed following the complex survey design.

\section{Results \\ Participant characteristics}

Participants included 424 men and 678 women. Men and women had the same distribution of age, with about $46 \%$ of them aged 60 years and more $(p$-value $=0.669)$. Also, around $50 \%$ of men and $46 \%$ of women were normal weight (p-value $=0.433$ ); $60 \%$ of men and $64 \%$ of women had low educational level (up to 8 years of study) (p-value $=0.069$ ) and $83 \%$ of men and $84 \%$ of women had a maximum per capita income of $\mathrm{R} \$$ $1,000$ per month ( $\mathrm{p}$-value $=0.599)$. A significantly higher proportion of women compared with men were of white skin color $(63 \%$ vs. $57 \%$, p-value = $0.040)$, non-smokers ( $85 \%$ vs. $76 \%$, p-value $<0.001)$, non-alcohol drinkers $(62 \%$ vs. $41 \%$, $\mathrm{p}$-value $<0.001)$ and with insufficient/sedentary physical activity level (55\% vs. $40 \%$, p-value $<0.001$ ) (data not shown).

\section{Dietary patterns composition and interpretability}

Table 2 shows the communalities of the dietary variables as well as the factor-loading matrix of the dietary patterns derived from EFA according to different rotation methods. The KMO test and Bartlett's sphericity test confirmed the sample adequacy for factor analysis $(\mathrm{KMO}=0.59$ and $\mathrm{p}<0.001$, respectively). The percentage of variance explained by each factor was quite similar across rotation methods, ranging from 5.15 to 5.21 to the Factor 1 and from 4.43 to 4.52 to the Factor 2. Considering factor loadings $\geq|0.20|$, the composition of the first dietary pattern (Factor 1) extracted by varimax rotation was slightly different from that extracted by both oblique rotations, Promax and Oblimin. The Factor 1 extracted by varimax rotation is composed of the traditional foods consumed by the Brazilian population namely rice, beans, sugar, white breads, butter and margarine, beef (positive loadings) and lowfat milk (negative loading). The Factor 1 patterns extracted by promax and oblimin rotation were identical to each other and included the aforementioned foods plus whole breads and white cheese, both with negative loadings. The second dietary pattern (Factor 2) was similar across factor rotations and was composed of salad dressing, leafy vegetables, non-leafy vegetables, spices, whole breads, white cheese, fruits and fruit juices. Among the food groups evaluated, salad dressing, rice, beans, leafy and non-leafy-vegetables were those with the highest percentage of variance explained by the factors, i.e., with the highest communalities.

Increasing the factor loading cut-off from $\geq$ $|0.20|$ to $\geq|0.25|$, the differences in Factor 1 across rotation methods were no longer observed. This factor was comprised of only four food items which characterize Brazilian staple foods, i.e., rice, beans, sugar and white breads. The Factor 2 extracted by varimax and promax rotations had a similar composition including foods consumed in a typical vegetable-based diet: salad dressing, leafy vegetables, non-leafy vegetables and spices. With respect to oblimin rotation, the Factor 2 comprised all the aforementioned vegetable foods plus whole breads.

\section{Construct validity of dietary patterns}

Table 3 presents the CFA results according to the factor loading cut-off $\geq|0.20|$ and different rotation methods. Regardless of rotation, the factor loadings were statistically significant for all dietary patterns ( $p$-value $<0.05$ ) and similar to the factor loadings obtained in EFA. Since promax and oblimin are oblique rotations and produced identical dietary patterns at cut-off $\geq$ $|0.20|$, the results of the CFA for these rotations were also identical. It should be pointed out that promax and oblimin produced dietary patterns with small but significant correlations $(r=0.17$, $\mathrm{p}$-value $<0.01$ ) (data not shown). Irrespective of the factor rotation applied, none of the dietary patterns derived showed an acceptable model fit based on the fit indexes evaluated other than SRMR (whose values were $<0.08$ ).

The factor loadings of all food items showed statistical significance at cut-off $\geq|0.25|$ for both orthogonal and oblique rotations (Table 4). The promax rotation, however, showed a better model fit than either varimax or oblimin. Although no differences were observed in the composition of the dietary patterns derived by varimax and promax rotations, the CFI, TLI, RMSEA and SRMR indicated a better fit for promax than for varimax. The oblimin rotation produced the worst result, with the CFI and TLI values being $<0.90$. The interfactor correlation was small but significant with both promax $(\mathrm{r}=0.19, \mathrm{p}$-value $<0.01)$ and oblimin rotations $(r=0.18, p$-value $<0.01)$ (data not shown).

\section{Discussion}

This study was the first to provide evidence about the effects of different rotation methods in EFA 
Table 2

Factor-loading matrix for dietary patterns derived according to different rotation methods. Health Survey of the City of São Paulo, Brazil, $2008-2011$.

\begin{tabular}{|c|c|c|c|c|c|c|c|}
\hline \multirow[t]{2}{*}{ Food groups } & \multicolumn{2}{|c|}{ Varimax rotation } & \multicolumn{2}{|c|}{ Promax rotation } & \multicolumn{2}{|c|}{ Oblimin rotation } & \multirow[t]{2}{*}{ Communality } \\
\hline & Factor 1 & Factor 2 & Factor 1 & Factor 2 & Factor 1 & Factor 2 & \\
\hline Rice & 0.72 & 0.06 & 0.72 & 0.13 & 0.71 & 0.06 & 0.52 \\
\hline Beans & 0.67 & -0.03 & 0.67 & 0.03 & 0.67 & -0.03 & 0.45 \\
\hline Sugar & 0.28 & -0.02 & 0.28 & 0.01 & 0.29 & -0.02 & 0.08 \\
\hline Breads/Toasts/Crackers & 0.25 & -0.01 & 0.25 & 0.02 & 0.25 & -0.01 & 0.06 \\
\hline Butter and margarine & 0.24 & 0.06 & 0.23 & 0.09 & 0.23 & 0.06 & 0.06 \\
\hline Beef & 0.20 & 0.10 & 0.19 & 0.12 & 0.18 & 0.10 & 0.05 \\
\hline Low-fat and skim milk & -0.21 & 0.15 & -0.22 & 0.13 & -0.23 & 0.15 & 0.07 \\
\hline Salad dressing & 0.19 & 0.73 & 0.16 & 0.75 & 0.08 & 0.74 & 0.57 \\
\hline Leafy vegetables & 0.10 & 0.62 & 0.07 & 0.63 & 0.00 & 0.63 & 0.39 \\
\hline Non-leafy vegetables * & 0.00 & 0.58 & -0.03 & 0.58 & -0.09 & 0.59 & 0.34 \\
\hline Spices & 0.05 & 0.32 & 0.03 & 0.32 & 0.00 & 0.32 & 0.10 \\
\hline Whole breads & -0.19 & 0.24 & -0.20 & 0.22 & -0.23 & 0.25 & 0.10 \\
\hline White cheese & -0.18 & 0.24 & -0.20 & 0.22 & -0.22 & 0.24 & 0.09 \\
\hline Fruits & -0.14 & 0.23 & -0.16 & 0.22 & -0.18 & 0.23 & 0.07 \\
\hline Fruit juices & -0.01 & 0.22 & -0.02 & 0.22 & -0.05 & 0.23 & 0.05 \\
\hline Eggs & 0.17 & 0.11 & 0.16 & 0.13 & 0.15 & 0.11 & 0.04 \\
\hline Whole milk & 0.15 & 0.00 & 0.15 & 0.02 & 0.15 & 0.00 & 0.02 \\
\hline Processed meat & 0.14 & 0.09 & 0.14 & 0.10 & 0.13 & 0.09 & 0.03 \\
\hline Coffee and tea & 0.14 & -0.01 & 0.14 & 0.00 & 0.14 & -0.01 & 0.02 \\
\hline Poultry & 0.10 & 0.14 & 0.09 & 0.14 & 0.08 & 0.14 & 0.03 \\
\hline Soda pop & 0.08 & -0.02 & 0.08 & -0.01 & 0.09 & -0.02 & 0.01 \\
\hline Pork & 0.05 & 0.00 & 0.05 & 0.01 & 0.05 & 0.00 & 0.00 \\
\hline Alcoholic beverages & 0.02 & 0.05 & 0.02 & 0.05 & 0.01 & 0.05 & 0.00 \\
\hline Salty snacks & 0.02 & 0.07 & 0.01 & 0.07 & 0.01 & 0.07 & 0.01 \\
\hline Chocolate powder & 0.01 & 0.05 & 0.01 & 0.05 & 0.00 & 0.05 & 0.00 \\
\hline Cold cuts & 0.01 & 0.07 & 0.01 & 0.07 & 0.00 & 0.07 & 0.01 \\
\hline Other dairy products & -0.01 & 0.15 & -0.02 & 0.14 & -0.04 & 0.15 & 0.02 \\
\hline Canned vegetables & -0.01 & 0.14 & -0.02 & 0.14 & -0.04 & 0.15 & 0.02 \\
\hline Yellow cheese & -0.03 & 0.09 & -0.04 & 0.09 & -0.05 & 0.09 & 0.01 \\
\hline Cakes/Confectionery products & -0.07 & 0.09 & -0.07 & 0.09 & -0.08 & 0.09 & 0.01 \\
\hline Pulses & -0.07 & 0.08 & -0.07 & 0.07 & -0.08 & 0.08 & 0.01 \\
\hline Sandwiches/Salty baked goods & -0.09 & -0.04 & -0.09 & -0.05 & -0.09 & -0.04 & 0.01 \\
\hline Fatty Sauces/Creams/Mayonnaise & -0.11 & 0.06 & -0.11 & 0.05 & -0.12 & 0.06 & 0.02 \\
\hline Pasta & -0.12 & 0.01 & -0.12 & 0.00 & -0.12 & 0.01 & 0.01 \\
\hline Eigenvalues & 1.76 & 1.51 & 1.75 & 1.51 & 1.77 & 1.54 & - \\
\hline Variance explained (\%) & 5.17 & 4.46 & 5.15 & 4.43 & 5.21 & 4.52 & - \\
\hline
\end{tabular}

* Excluding roots and tubers.

Note: values in bold: factor loadings $\geq|0.20|$; values in bold and italic: factor loadings $\geq|0.25|$. KMO $=0.59$; Bartlett's sphericity test ( $p<0.001$ ).

on composition, interpretability and construct validity of empirically derived dietary patterns and contributed to outline important issues as regards to this analysis. The only other study concerning factor rotation methods in nutritional epidemiology was published by Bountziouka \& Panagiotakos 5 who evaluated these effects on short-term repeatability of four dietary patterns derived through principal component analysis (PCA). The authors observed that, irrespective of rotation type used, i.e., orthogonal (varimax; quartimax) or oblique (promax; direct oblimin), the short-term repeatability of the dietary patterns extracted was low.

The most noticeable findings of this study were the effects of rotation method on the com- 
Confirmatory factor analysis of dietary patterns derived according to factor loadings $\geq|0.20|$ * and rotation criteria. Health Survey of the City of São Paulo, Brazil, 2008-2011.

\begin{tabular}{|c|c|c|c|c|c|}
\hline \multicolumn{2}{|c|}{ Varimax rotation } & \multicolumn{2}{|c|}{ Promax rotation } & \multicolumn{2}{|c|}{ Oblimin rotation } \\
\hline Food groups & $\begin{array}{l}\text { Factor loading } \\
\text { (SE) }\end{array}$ & Food groups & $\begin{array}{l}\text { Factor loading } \\
\qquad(\mathrm{SE})\end{array}$ & Food groups & $\begin{array}{l}\text { Factor loading } \\
\text { (SE) }\end{array}$ \\
\hline Factor 1 & & Factor 1 & & actor 1 & \\
\hline Rice & $0.79(0.04) * \star$ & Rice & $0.73(0.04) * \star$ & Rice & $0.73(0.04) *$ \\
\hline Beans & $0.66(0.04) * *$ & Beans & $0.68(0.04) * *$ & Beans & $0.68(0.04) *$ \\
\hline Beef & $0.23(0.04) * *$ & Sugar & $0.26(0.04) * \star$ & Sugar & $0.26(0.04)$ * \\
\hline Sugar & $0.23(0.04) * \star$ & Breads/Toasts/Crackers & $0.23(0.05) * \star$ & Breads/Toasts/Crackers & $0.23(0.05)$ * \\
\hline Butter and margarine & $0.21(0.05) * \star$ & Butter and margarine & 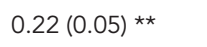 & Butter and margarine & $0.22(0.05)$ * \\
\hline Breads/Toasts/Crackers & $0.19(0.05) * \star$ & White cheese & $-0.22(0.04) * \star$ & White cheese & $-0.22(0.04) *$ \\
\hline \multirow[t]{2}{*}{ Low-fat and skim milk } & $-0.15(0.04) * \star$ & Whole breads & $-0.21(0.04) * *$ & Whole breads & $-0.21(0.04) *$ \\
\hline & & Low-fat and skim milk & $-0.17(0.03) * \star$ & Low-fat and skim milk & $-0.17(0.03)$ * \\
\hline Factor 2 & & Factor 2 & & actor 2 & \\
\hline Salad dressing & $0.76(0.03) * \star$ & Salad dressing & $0.78(0.03) * \star$ & Salad dressing & $0.78(0.03)$ * \\
\hline Leafy vegetables & $0.64(0.03) * \star$ & Leafy vegetables & $0.63(0.03) * \star$ & Leafy vegetables & $0.63(0.03)$ * \\
\hline Non-leafy vegetables & $0.57(0.03) * \star$ & Non-leafy vegetables & $0.56(0.03) * \star$ & Non-leafy vegetables & $0.56(0.03)$ * \\
\hline Spices & $0.33(0.04) * \star$ & Spices & $0.32(0.04) * \star$ & Spices & $0.32(0.04)$ * \\
\hline White cheese & $0.20(0.04) * \star$ & White cheese & $0.23(0.04) * \star$ & White cheese & $0.23(0.04)$ * \\
\hline Fruit juices & $0.20(0.04) * \star$ & Whole Breads & $0.22(0.04) * \star$ & Whole breads & $0.22(0.04)$ * \\
\hline Whole breads & $0.19(0.04) * \star$ & Fruit juices & 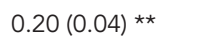 & Fruit juices & $0.20(0.04)$ * \\
\hline Fruits & $0.19(0.04) * \star$ & Fruits & $0.18(0.04) * \star$ & Fruits & $0.18(0.04)$ * \\
\hline Goodness-of-fit indexes & & Goodness-of-fit indexes & & oodness-of-fit indexes & \\
\hline$\chi^{2}(90$ d.f. $) *$ & 634.14 & $\chi^{2}(74$ d.f. $)$ * & 538.39 & $\chi^{2}$ (74 d.f.) $)^{\star \star}$ & 538.39 \\
\hline$\chi^{2 / d . f .}$ & 7.05 & $\chi^{2} /$ d.f. & 7.28 & $\chi^{2} /$ d.f. & 7.28 \\
\hline RMSEA $(90 \% \mathrm{Cl})$ & $0.07(0.06 ; 0.08)$ & RMSEA $(90 \% \mathrm{Cl})$ & $0.08(0.07 ; 0.08)$ & RMSEA $(90 \% \mathrm{Cl})$ & $0.08(0.07 ; 0.08)$ \\
\hline $\mathrm{CFI}$ & 0.66 & $\mathrm{CFI}$ & 0.70 & CFI & 0.70 \\
\hline TLI & 0.60 & TLI & 0.63 & TLI & 0.63 \\
\hline SRMR & 0.07 & SRMR & 0.07 & SRMR & 0.07 \\
\hline
\end{tabular}

CFI: comparative fit index; $\chi^{2} /$ d.f.: adjusted Chi-squared test; RMSEA, residual mean standard error of approximation; SE: square error; SRMR: standardized root mean square residual; TLI: Tucker-Lewis index.

* Factor loadings $\geq|0.20|$ from exploratory factor analysis;

** p-value $<0.01$

position and interpretability of dietary patterns that may be influenced by the factor loading cutoff selected during EFA. Considering the factor loading cut-off $\geq|0.20|$, differences in composition and in interpretability of the first dietary pattern (Factor 1) but not of the second pattern (Factor 2) were observed between orthogonal and oblique rotations, i.e., between varimax and promax/oblimin rotations. These differences may be explained by the cross-loadings $\geq|0.20|$ of two food groups - white cheeses and whole breads that occurred with oblique rotations. However, increasing the factor loading cut-off from $\geq|0.20|$ to $\geq|0.25|$ eliminated the cross-loadings and also the differences in the composition of the Factor 1 across rotation methods. Despite the differences produced on dietary patterns composition, the rotation methods produced similar results concerning the percentage of variance explained for Factors 1 and 2 .

Differences in composition and interpretability of the dietary patterns across rotation methods may be less remarkable at higher factor loading cut-offs because this can contribute to reduce the occurrence of cross-loadings in the factor structure. It should be emphasized that 
Confirmatory factor analysis of dietary patterns derived according to factor loadings $\geq|0.25|$ * and rotation criteria. Health Survey of the City of São Paulo, Brazil, 2008-2011.

\begin{tabular}{|c|c|c|c|c|c|}
\hline \multicolumn{2}{|c|}{ Varimax rotation } & \multicolumn{2}{|c|}{ Promax rotation } & \multicolumn{2}{|c|}{ Oblimin rotation } \\
\hline Food groups & $\begin{array}{l}\text { Factor loading } \\
\text { (SE) }\end{array}$ & Food Groups & $\begin{array}{l}\text { Factor loading } \\
\text { (SE) }\end{array}$ & Food groups & $\begin{array}{l}\text { Factor loading } \\
\text { (SE) }\end{array}$ \\
\hline Factor 1 & & Factor 1 & & Factor 1 & \\
\hline Rice & $0.75(0.05) * \star$ & Rice & $0.79(0.06) * \star$ & Rice & $0.79(0.06)$ * \\
\hline Beans & $0.71(0.06) * \star$ & Beans & $0.67(0.06) * \star$ & Beans & $0.67(0.06)$ * \\
\hline Sugar & $0.22(0.04) * \star$ & Sugar & $0.21(0.04) * \star$ & Sugar & $0.21(0.04)$ * \\
\hline Breads/Toasts/Crackers & $0.16(0.04) * \star$ & Breads/Toasts/Crackers & $0.16(0.04) * \star$ & Breads/Toasts/Crackers & $0.16(0.04) *$ \\
\hline Factor 2 & & Factor 2 & & Factor 2 & \\
\hline Salad dressing & $0.82(0.03) * \star$ & Salad dressing & $0.84(0.03) * \star$ & Salad dressing & $0.82(0.03)$ * \\
\hline Leafy vegetables & $0.61(0.03) * \star$ & Leafy vegetables & $0.61(0.03) * *$ & Leafy vegetables & $0.61(0.03)$ * \\
\hline Non-leafy vegetables & $0.54(0.03) * \star$ & Non-leafy vegetables & $0.53(0.03) * \star$ & Non-leafy vegetables & $0.54(0.03)$ * \\
\hline \multirow[t]{2}{*}{ Spices } & $0.32(0.04) * *$ & Spices & $0.32(0.04) * \star$ & Spices & $0.32(0.04) *$ \\
\hline & & & & Whole breads & $0.15(0.04)$ * \\
\hline Goodness-of-fit indexes & & Goodness-of-fit indexes & & Goodness-of-fit indexes & \\
\hline$\chi^{2}(20$ d.f. $)$ * & 88.27 & $\chi^{2}(19$ d.f. $) * \star$ & 69.68 & $\chi^{2}(26$ d.f. $) * \star$ & 147.63 \\
\hline$\chi^{2} /$ d.f. & 4.41 & $\chi^{2} /$ d.f. & 3.67 & $\chi^{2} /$ d.f. & 5.68 \\
\hline RMSEA (90\%CI) & $0.06(0.04,0.07)$ & RMSEA (90\%Cl) & $0.05(0.04,0.06)$ & RMSEA (90\%Cl) & $0.07(0.06,0.08)$ \\
\hline $\mathrm{CFI}$ & 0.92 & $\mathrm{CFI}$ & 0.94 & $\mathrm{CFI}$ & 0.87 \\
\hline TLI & 0.89 & TLI & 0.91 & TLI & 0.82 \\
\hline SRMR & 0.05 & SRMR & 0.04 & SRMR & 0.05 \\
\hline
\end{tabular}

CFI: comparative fit index; $\chi^{2} /$ d.f.: adjusted Chi-squared test; RMSEA, residual mean square error of approximation; SE: standard error; SRMR: standardized root mean square residual; TLI: Tucker-Lewis index.

* Factor loadings $\geq|0.25|$ from exploratory factor analysis;

** $\mathrm{p}$-value $<0.01$.

although all rotations selected for this study aimed to reduce the cross-loadings toward zero $8,41,42,43$, only the orthogonal varimax attained this purpose in both factor loading cut-offs. Therefore, researchers must also consider whether crossloadings are interesting or not when selecting the rotation method and the factor loading cut-off for EFA in dietary pattern studies.

Another noticeble finding concerns the construct validity of the dietary patterns derived with different rotation methods and factor loading cut-offs. Regardless of rotation, the factors derived with the factor loading cut-off $\geq|0.20|$ did not show acceptable construct validity. Even if it was adequate to produce meaningful dietary patterns, this cut-off was quite low to select food items that could be valid to depict the dietary patterns of the population evaluated.

In fact, only the factors derived by promax rotation with a factor loading cut-off $\geq|0.25|$ in EFA showed an acceptable construct validity as indicated by all goodness-of-fit indexes except the adjusted Chi-squared test. Differently from the other indexes evaluated in this study, the adjusted Chi-squared test is directly influenced by the sample size and the number of variables observed. Hence, the larger the sample size and the number of variables, higher is the Chi-squared value. Also, the higher the number of free parameters of the model, lower is the number of degrees of freedom of the test 32 . Considering the limitations of the adjusted Chi-squared test, experts recommend evaluating model fit by different goodness-of-fit indexes including those analyzed in this study, because they reflect different aspects of the model adjustment 54 .

It should also be mentioned that the orthogonal varimax rotation extracted factors with the same variables as the promax rotation, but without construct validity. It means that the assumption of independence of the factor structure was inappropriate for these data. Actually, the correlation between factors derived by oblique promax rotation was significant different to 
zero $(r=0.19)$. In this way, researchers must also be cognizant that the choice of an orthogonal rotation solely based on their independent assumption of the factors may fail to extract valid factors. Hence, it is important to verify whether this assumption is appropriate before deriving and interpreting the dietary patterns. If so, both orthogonal and oblique rotations will probably lead to similar factors at high factor loading cutoffs (e.g., $\geq|0.25|$ ).

Moreover, it must be considered that the correlation between dietary patterns may produce factor scores that are also correlated, and thus, caution is needed when planning to use these scores as dependent variables in regression models. Since the independency assumption of the observations is required for traditional regression models, a methodological alternative is to apply the exploratory structural equation modeling (ESEM). This method has emerged as a suitable multivariate statistical modeling technique to examine associations between latent (e.g., dietary patterns) and observed variables, allowing for multiple dependent and independent variables in a single equation 30 . The ESEM relies on the covariance structure of the observed variables and can be interpreted as a combination of EFA, CFA and regression analysis, and is indicated when the researcher has a weak hypothesis about how multiple-observed variables load on the factors 30 . Another advantage of the ESEM to dietary pattern analysis includes the possibility of testing the significance of factor loadings in lieu of applying predetermined factor loading cut-offs, and this reduces the subjectivity during modeling. More details about this method can be found in Asparouhov \& Muthén 55.

This study has some methodological features that should be addressed. First, the dietary patterns derived were based on data collected by a short-term dietary assessment method, i.e., by two non-consecutive $24 \mathrm{HR}$. It is known that, although the short-term dietary assessment methods provide detailed data about types and amounts of foods consumed 56, they lead to a large within-person variation of dietary estimates. This variation could attenuate the correlation matrix of the foods and thus the factor loadings observed in each dietary pattern. To overcome this, the food groups were adjusted for the within-person variation through the MSM before proceeding to factor analysis as performed by Selem et al. ${ }^{49}$. It is worth mentioning that this adjustment may be considered a methodologi- cal advance in dietary pattern analysis and may have contributed to enhance the reliability of the results.

Second, the estimation method used in EFA to derive dietary patterns in this study differed from the frequently used method in other dietary pattern studies. The robust maximum likelihood parameter estimation (MLR) was chosen in EFA in lieu of the principal component factor method (PCF) because it was also available for use in CFA as an appropriate estimator to non-normally distributed data 31 . The use of MLR in both EFA and CFA aimed to avoid a misinterpretation of the results that might occur if different estimation procedures were applied for deriving dietary patterns and for assessing their construct validity.

Finally, this study could not evaluate the effects of rotation methods on composition, interpretability and construct validity of dietary patterns derived at the most applied factor loading cut-off, i.e., $\geq|0.30|$, because it would lead to a very restrictive number of food items for factor's interpretability and CFA purposes. Nonetheless, the authors ensured methodological strictness by selecting two other cut-offs $(\geq|0.20|$ and $\geq$ $|0.25|)$ that are also commonly applied in dietary pattern studies $34,35,36,37,38,39,40,44,45,46,47,48,49$.

In summary, the effects of rotation methods on composition, interpretability and construct validity of dietary patterns differed according to the factor loading cut-off used in EFA. Less remarkable differences in composition and interpretability of the dietary patterns according to rotation method may occur at higher cut-offs such as $\geq|0.25|$ compared with lower ones $(\geq|0.20|)$. Irrespective of rotation method, dietary patterns derived at factor loading cut-off $\geq|0.20|$ did not show acceptable construct validity. At factor loading cut-offs $\geq|0.25|$, however, the promax rotation showed a better model fit than either varimax or oblimin. Hence, the authors recommend performing at least one orthogonal and one oblique rotation in EFA, applying the factor loading cut-off and then comparing the factor solutions. Moreover, the CFA should be conducted to test the construct validity of the dietary patterns derived and to verify whether the factor loading cut-off chosen during the EFA is adequate or not to select the food items that truly depict dietary patterns of the population. Further studies are needed to investigate the effects of other rotation methods on the dietary patterns derived in different populations. 


\section{Resumen}

El estudio tuvo como objetivo investigar los efectos de los métodos de rotación en la interpretabilidad y validez de un constructo de patrones alimentarios, derivados de una muestra representativa de 1.102 adultos brasileños. Los patrones se derivaron de un análisis factorial exploratorio. Se aplicaron las rotaciones ortogonal (varimax) y oblicua (promax, oblimin directa). La validez de constructo de los patrones fue evaluada por un análisis factorial confirmatorio, según los puntos de corte de cargas factoriales: $(\geq|0,20| y \geq|0.25|)$. Se analizaron los índices de ajuste del modelo. Se observaron diferencias en la composición e interpretación del primer factor entre varimax $y$ promax/oblimin en el punto de corte $\geq|0,20|$. En el punto de corte $\geq|0,25|$, ya no se observaron diferencias. Ninguno de los patrones derivados en el punto de corte $\geq|0,20|$ presentaron un ajuste del modelo aceptable. En el punto de corte $\geq|0,25|$, la rotación promax produjo el mejor ajuste. Los efectos de las rotaciones factoriales en los patrones fueron variables, según el punto de corte de carga factorial utilizado en análisis factorial exploratorio.

Consumo de Alimentos; Hábitos Alimenticios; Nutrición en Salud Pública; Análisis Factorial

\section{References}

1. Hu FB. Dietary pattern analysis: a new direction in nutritional epidemiology. Curr Opin Lipidol 2002; 13:3-9.

2. Messina M, Lampe JW, Birt DF, Appel LJ, Pivonka E, Berry B, et al. Reductionism and the narrowing nutrition perspective: time for reevaluation and emphasis on food synergy. J Am Diet Assoc 2001; 101:1416-9.

3. Jacob DR, Steffen LM. Nutrients, foods, and dietary patterns as exposures in research: a framework for food synergy. Am J Clin Nutr 2003; 78 Suppl: 508S-13S.

4. Bandalos DL, Boehm-Kaufman MR. Four common misconceptions in exploratory factor analysis. In: Lance CE, Vanderberg RJ, editors. Statistical and methodological myths and urban legends: doctrine, verity and fable in the organizational and social sciences. New York: Routledge; 2009. p. 61-87.

\section{Contributors}

M. A. Castro proposed the analytical methodology for the study, carried out the statistical analysis and wrote the manuscript. V. T. Baltar provided expertise in statistical analysis and contributed in the manuscript write-up. S. S. C. Selem contributed towards the data anlaysis of food consumption and the manuscript write-up. D. M. L. Marchioni supervised the statistical analysis, provided expertise in the data analysis of food consumption and carried out a critical revision of the manuscript. R. M. Fisberg coordinated the data collection, collaborated with the write-up of the manuscript and was responsible for a critical revision of the text.

\section{Acknowledgments}

To CNPq (process: 473100/2009-6;143115/2011-1) and FAPESP (process: 2009/15831-0) for the financial support.
5. Bountziouka V, Panagiotakos DB. The role of rotation type used to extract dietary patterns through principal component analysis, on their short-term repeatability. J Data Sci 2012; 10:19-36.

6. Rietveld T, Van Hout R. Statistical techniques for the study of language and language behaviour. Berlin/New York: Mouton de Gruyter; 1993.

7. Floyd FJ, Widaman KF. Factor analysis in the development and refinement of clinical assessment instruments. Psychol Assess 1995; 7:286-99.

8. Saas DA. Factor loading estimation error and stability using exploratory factor analysis. Education Psychology Measurement 2010; 70:557-77.

9. Newby PK, Muller D, Tucker KL. Associations of empirically derived eating patterns with plasma lipid biomarkers: a comparison of factor and cluster analysis methods. Am J Clin Nutr 2004; 80: 759-67. 
10. Varraso R, Garcia-Aymerich J, Monier F, Le Moual N, De Batlle J, Miranda G, et al. Assessment of dietary patterns in nutritional epidemiology: principal component analysis compared with confirmatory factor analysis. Am J Clin Nutr 2012; 96 : 1079-92.

11. Bell RA, Quandt SA, Vitolins MZ, Arcury TA. Dietary patterns of older adults in a rural, tri-ethnic community: a factor analysis approach. Nutr Res 2003; 23:1379-90.

12. Frémeaux AE, Hosking J, Metcalf BS, Jeffery AN, Voss LD, Wilkin TJ. Consistency of children's dietary choices: annual repeat measures from 5 to 13 years (EarlyBird 49). Br J Nutr 2011; 106:725-31.

13. Gittelsohn J, Wolever TMS, Harris SB, Harris-Giraldo R, Hanley AJ, Zinman B. Specific patterns of food consumption and preparation are associated with diabetes and obesity in a native Canadian community. J Nutr 1998; 128:541-7.

14. Iimuro S, Yoshimura Y, Umegaki H, Sakurai T, Araki A, Ohashi Y, et al. Dietary pattern and mortality in Japanese elderly patients with type 2 diabetes mellitus: does vegetable- and fish-rich diet improve mortality? An exploratory study. Geriatr Gerontol Int 2012; 12 Suppl 1:59-67.

15. Togo P1, Heitmann BL, Sørensen TI, Osler M. Consistency of food intake factors by different dietary assessment methods and population groups. $\mathrm{Br} \mathrm{J}$ Nutr 2003; 90:667-78.

16. De Stefani E, Boffetta P, Fagundes RB, Deneo-Pellegrini $H$, Ronco AL, Acosta G, et al. Nutrient patterns and risk of squamous cell carcinoma of the esophagus: a factor analysis in Uruguay. Anticancer Res 2008; 28:2499-506.

17. De Stéfani E, Aune D, Deneo-Pellegrini H, Boffetta P, Ronco AL, Correa P. Dietary patterns and risk of gastric cancer: a factor analysis in Uruguay. Medical Hypoteses and Research 2009; 5:37-46.

18. Peter JP. Construct validity: a review of basic issues and marketing practices. J J Mark Res 1981; 18 : 133-45.

19. Fabrigar LR, MacCallum RC, Weneger DT, Strahan EJ. Evaluating the use of exploratory factor analysis in psychological research. Psychol Methods 1999; 4:272-99.

20. Rahim MA, Magner NR. Confirmatory factor analysis of the styles of handling interpersonal conflict: first-order factor model and its invariance across groups. J Appl Psychol 1995; 80:122-32.

21. Raper N, Perloff B, Ingwersen L, et al. An overview of USDA's Dietary Intake Data System. J Food Compost Anal 2004; 17:545-55.

22. Thompson FE, Subar AF, Loria CM, Reedy JL, Baranowski T. Need for technological innovation in dietary assessment. J Am Diet Assoc 2011; 110: 48-51.

23. Pinheiro AVB, Lacerda EMA, Benzecry EH, Gomes MCS, Costa VM. Tabela para avaliação do consumo alimentar em medidas caseiras. 4a Ed. São Paulo: Editora Atheneu; 2001.
24. Fisberg RM, Villar BS. Manual de receitas e medidas caseiras para cálculo de inquéritos alimentares: manual elaborado para auxiliar o processamento de inquéritos alimentares. São Paulo: Editora Signus; 2002.

25. Souza RLV, Madruga SW, Gigante DP, Santos IS, Barros AJD, Assunção MCF. Padrões alimentares e fatores associados entre crianças de um a seis anos de um município do Sul do Brasil. Cad Saúde Pública 2013; 29:2416-26.

26. Vilela AMF, Sichieri R, Pereira RA, Cunha DB, Rodrigues PRM, Gonçalves-Silva RM, et al. Dietary patterns associated with anthropometric indicators of abdominal fat in adults. Cad Saúde Pública 2014; 30:502-10.

27. Cunha DB, Almeida RMVR, Sichieri R, Pereira RA. Association of dietary patterns with BMI and waist circumference in a low-income neighbourhood in Brazil. Br J Nutr 2010; 104:908-13.

28. Sichieri R, Castro JFG, Moura AS. Fatores associados ao padrão de consumo alimentar da população urbana brasileira. Cad Saúde Pública 2003; 19 Suppl 1:S47-53.

29. Harttig U, Haubrock J, Knüppel S, Boeing H; EFCOVAL Consortium. The MSM program: webbased statistics package for estimating usual dietary intake using the Multiple Source Method. Eur J Clin Nutr 2011; 65 Suppl 1:S87-91.

30. Kline RB. Principles and practice of Structural Equation Modelling. 2nd Ed. New York: The Guilford Press; 2005.

31. Muthén LF, Muthén BO. Mplus user's guide: Mplus statistical analysis with latent variables. $6^{\text {th }}$ Ed. Los Angeles: Muthén \& Muthén; 2010.

32. Hair JF, Black B, Babin B, Anderson RE, Tatham RL. Multivariate data analysis. $6^{\text {th }}$ Ed. New Jersey: Prentice Hall; 2005

33. Hayton JC, Allen DG, Scarpello V. Factor retention decisions in exploratory factor analysis: a tutorial on parallel analysis. Organizational Research Methods 2004; 7:191-205.

34. Velie EM, Schairer C, Flood A, He JP, Khattree R, Schatzkin A. Empirically derived dietary patterns and risk of postmenopausal breast cancer in a large prospective cohort study. Am J Clin Nutr 2005; 82:1308-19.

35. Newby PK, Weismayer C, Akesson A, Tucker KL, Wolk A. Long-term stability of food patterns identified by use of factor analysis among Swedish women. J Nutr 2006; 136:626-33.

36. Harriss LR, English DR, Powles J, Giles GG, Tonkin AM, Hodge AM, et al. Dietary patterns and cardiovascular mortality in the Melbourne Collaborative Cohort Study. Am J Clin Nutr 2007; 86:221-9.

37. Marchioni DML, Fisberg RM, Góis Filho JF, Kowalski LP, Carvalho MB, Abrahão M, et al. Dietary patterns and risk of oral cancer: a case-control study in São Paulo, Brazil. Rev Saúde Pública 2007; 41:19-26. 
38. McNaughton SA, Mishra GD, Stephen AM, Wadsworth ME. Dietary patterns throughout adult life are associated with body mass index, waist circumference, blood pressure, and red cell folate. J Nutr 2007; 137:99-105.

39. Lutsey PL, Steffen LM, Stevens J. Dietary intake and the development of the metabolic syndrome: the Atherosclerosis risk in communities study. Circulation 2008; 117:754-61.

40. Safari A, Shariff ZM, Kandiah M, Rashidkhani B, Fereidooni F. Dietary patterns and risk of colorectal cancer in Tehran Providence: a case-control study. BMC Public Health 2013; 13:222.

41. Kaiser HF. The varimax criterion for analytic rotation in factor analysis. Psychometrika 1958; 23:187-200.

42. Abdi H. Factor rotations in factor analyses. In: Lewis-Beck M, Bryman A, Futing T, editors. Encyclopedia for research methods for the social sciences. Newbury Park: Sage; 2003. p. 792-5.

43. Browne MW. An overview of analytic rotation in exploratory factor analysis. Multivariate Behav Res 2001; 36:111-50.

44. Hong S, Song YJ, Lee KH, Lee HS, Lee M, Jee SH, et al. A fruit and dairy dietary pattern is associated with a reduced risk of metabolic syndrome. Metab Clin Exper 2012; 61:883-90.

45. Shin J-Y, Kim J-M, Kim Y. Associations between dietary patterns and hypertension among Korean adults: the Korean National Health and Nutrition Examination Survey (2008-2010). Nutr Res Pract 2013; 7:224-32.

46. Stricker MD, Onland-Moret NC, Boer JMA, van der Schouw YT, Verschuren WMM, May AM, et al. Dietary patterns derived from principal componentand k-means cluster analysis: long-term association with coronary heart disease and stroke. Nutr Metab Cardiovasc Dis 2013; 23:250-6.

47. Kim JH, Lee JE, Jung JK. Dietary pattern classifications and the association with general obesity and abdominal obesity in Korean women. J Acad Nutr Diet 2012; 112:1550-9.
48. Miller PE, Morey MC, Hartman TJ, Snyder DC, Sloane R, Cohen HJ, et al. Dietary patterns differ between urban and rural older, long-term survivors of breast, prostate, and colorectal cancer and are associated with body mass index. J Acad Nutr Diet. 2012; 112:824-31.

49. Selem SSC, Castro MA, César CLG, Marchioni DML, Fisberg RM. Associations between dietary patterns and self-reported hypertension among Brazilian adults: a cross-sectional populationbased study. J Acad Nutr Diet 2014; 114:1216-22.

50. Bentler PM. Comparative fit indexes in structural models. Psychol Bull 1990; 107:238-46.

51. Bentler PM, Bonett DG. Significance tests and goodness of fit in the analysis of covariance structures. Psychol Bull 1980; 88:588-606.

52. Browne MW, Cudeck R. Alternative ways of assessing model fit. In: Bollen KA, Long JS, editors. Testing structural equation models. Newbury Park: Sage; 1993. p. 136-62.

53. Hu LT, Bentler PM. Cutoff criteria for fit indexes in covariance structure analysis: conventional criteria versus new alternatives. Struct Equ Modeling 1999; 6:1-55.

54. Hooper D, Coughlan J, Mullen MR. Structural equation modelling: guidelines for determining model fit. Eletronic Journal of Business Research Methods 2008; 6:53-60.

55. Asparouhov T, Muthén BO. Exploratory structural equation modeling. Struct Equ Modeling 2009; 16:397-438.

56. Tucker KL. Assessment of usual dietary intake in population studies of gene-diet interaction. Nutr Metab Cardiovasc Dis 2007; 17:74-81.

Submitted on 06/May/2014

Final version resubmitted on $31 / \mathrm{Jul} / 2014$

Approved on 12/Sep/20 14 